under a piston in a vertical open-top cylinder by the condensation of steam, and it may be Newcomen read a review of a book by Papin contained in the Philosophical Transactions of March 1697. Mr. Jenkins placed no credence on the story that Newcomen had been in correspondence with Hooke, as stated by Robison in the third edition of the "Encyclopaedia Britannica", and this story must be omitted from the history of the steam engine, at any rate until documentary evidence is forthcoming.

\section{Domestic Lighting}

THE summer school of electrical housecraft recently paid a visit to the Lighting Service Bureau of the Electric Lamp Manufacturers' Association. Mr. W. J. Jones laid stress on the need for adequate light in the home for reading and for carrying out domestic tasks. Practical demonstrations were given to prove his statements. He showed how good lighting helps the eye to see quickly, and hence under favourable conditions a task can be performed with greater accuracy and in less time. When a gramophone turntable with a disk of white cardboard marked by two intersecting lines is made to revolve, its speed seems to increase as the amount of light thrown on the disk is reduced. Actually the speed is kept constant, but so effective is the maximum illumination in reducing the apparent speed of the disk that it is difficult to believe that the speed keeps constant. When the disk is brightly lit, the eye has little difficulty in following the rotation of the lines, whereas when badly lit a confused whirl only is seen. The absorption power of decorations was demonstrated and the importance of using extra light to counteract the effects of a dark colour scheme or of decorations was insisted on. A talking film entitled the "Science of Seeing" has been prepared by the Bureau for loan to schools, etc. During his lecture, Mr. Jones asked his audience to choose the amount of light for the most comfortable seeing conditions in the lecture theatre. This was done by raising and lowering the lighting. Individual members chose illuminations lying between 20 and 75 foot-candles.

\section{Factors affecting Freedom of the Press}

Followne on the broadsheet on the state of the press in Great Britain, issued by Political and Economic Planning in 1935, the Press group of P.E.P. has now issued a further broadeast on the freedom of the press. Besides the various legal factors, such as the law of libel, which restrict publication in the press, there are other equally potent influences which may act in restraint of publication, such as advertizing influence, the private policy of a proprietor, or the pressure of public or semi-public bodies may be exerted in various ways which make it more and more difficult to voice emphatically the grievance of an individual or group against authority and monopoly. While absolute freedom of the press is neither possible nor desirable, there are strong arguments for keeping restrictions and external pressure of every kind to a minimum. Moreover, the selection or rejection of news for a newspaper is still mainly determined not by external influences, however powerful, but by the character and outlook of journalists. Where they are content to follow the line of least resistance, giving prominence to trivialities, and evading or ignoring important subjects and points of view that are unpopular or likely to arouse powerful opposition, the control of the press will in fact be determined by the barriers erected against free discussion, with fatal results. Bad journalism begins by driving out good and may end by causing the imposition of restrictions so severe that good, critical, informed and independent journalism is impossible. On the other hand, independent, courageous journalism creates and commands the admiration of independent and courageous people who are powerful enough to support it and defend it. The fate of the press is bound up with the fate of democracy, and in any type of State the press will have to fight harder to justify its existence against competition and encroachments of many kinds.

\section{Archæology in Indo-China}

No little success has been achieved by the first two expeditions of archæological exploration conducted by the Greater Indian Research Committee. This Committee was founded in 1934 under the chairmanship of Sir Francis Younghusband with the object of throwing light by field exploration on Indian cultural and colonial expansion throughout south-eastern Asia. An account of the results obtained up to the present is given by Dr. H. G. Quaritch Wales, the field director, in Discovery of November. The first expedition began work at Takuapa on the west coast of peninsular Siam. This has been identified with the Takola Mart of Ptolemy. Here the archæological evidence has demonstrated the existence of a considerable settlement of Siva worshippers of South Indian affinities, which flourished from the fourth to the eighth or ninth centuries of our era, and was frequented by Chinese and Islamic traders. Further, a line of communication with the west coast has been traced to the Bay of Bandon, where excavations have been carried out on the site of the ancient city of Chaiya, apparently the capital of a great Indianized empire. Even more important results were obtained by an expedition to a site in eastern central Siam, where in the remote Pasak valley in the vestiges of a city were discovered relics of the vanished culture of the great Fu-nan Empire, of which this had been an outlying emporium on the trade route to the Menam valley. This culture was overwhelmed and completely destroyed by the rise of the Kmers in the sixth century A.D. Here the most important discovery was that of an Indian brick temple, which is the earliest known example of Indian colonial architecture. Previous to this discovery, all early Indian colonial temples were thought to have been built of wood. Several examples of sculpture were also found of pure Gupta style.

\section{The Earliest Printed Book on the Magnet}

THE annotated catalogues of antiquarian booksellers who deal especially in old scientific books always make interesting and instructive reading to the student of the history of science. Sometimes 